\title{
Internal Marketing Based on the Hierarchy of Effects Model for the Life Insurance Industry
}

\author{
Ker-Tah Hsu \\ Correspondence: Ker-Tah Hsu, Department of International Business, National Taichung University of Education, 140 \\ Min-Shen Road, Taichung City 40306, Taiwan. E-mail:kthsu@mail.ntcu.edu.tw
}

Received: June 29, 2016

Accepted: July 25, 2016

Online Published: August 1, 2016

doi:10.5539/ibr.v9n10p1

URL: http://dx.doi.org/10.5539/ibr.v9n10p1

\begin{abstract}
The purpose of this study is to identify the extent to which ethical climate, leader-member exchange, and role clarity can be employed as business levers in internal marketing; the relationships among them are investigated using a conceptual model based on the hierarchy of effects model. From several major life insurance firms in Taiwan, 644 life insurance salespeople formed the basis of the empirical analysis in this study. Ethical climate is not only a feasible business practice for implementing internal marketing but also a basis for other managerial activities concerning internal marketing. Managerial activities arousing salespeople's perceptions of ethical climate, leader-member exchange, and role clarity may be useful in enhancing their job satisfaction, and in strengthening the organizational identification and organizational commitment of their salespeople. This study extends the internal marketing literature both by applying the principles of the hierarchy of effects model to internal marketing, and by examining the effects of ethical climate, leader-member exchange, and role clarity on job outcomes within such a context.
\end{abstract}

Keywords: internal marketing, ethical climate, leader-member exchange, role clarity

\section{Introduction}

The concept of internal marketing is particularly applicable to service industries (Cooper \& Cronin, 2000). A successful service company has a competitive advantage regarding external customers, partly because it has a competitive advantage concerning its internal customers, namely its employees. By treating employees as internal customers and satisfying their needs, employees gain organizational benefits that can encourage them to meet organizational marketing objectives, leading to the development of a more customer-conscious, market-oriented, and sales-minded workforce, thereby enhancing the organization. This places the firm in a superior position to deliver high-quality service, satisfying external customers and strengthening its competitive position (Papasolomou \& Vrontis, 2006).

The life insurance industry is an apt example of a service-intensive sector. Life insurance policies are complex and thus difficult for prospective policy holders to understand (Taek Yi et al., 2012). Therefore, policyholders rely heavily on salespeople for relevant information, entailing intensive interactions between the two parties (Schlager et al., 2011). Life insurance salespeople can be among the most crucial determinants of service quality and customer satisfaction, and in turn, the financial performance of life insurance companies. By implementing internal marketing, life insurance companies expect to develop salespeople who are further qualified and eager to provide a higher level of service quality. This further implies that a steep information asymmetry may be exploited by salespeople and should be addressed by internal marketing. In the internal marketing process, it is critical that managers act to change employee attitudes and behaviors.

Researchers have expanded the internal marketing concept by incorporating more variables. Researchers have also proposed general models of internal marketing, in which the categories and types of relevant variables and the causal relationships between them are theoretically systemized. For example, King and Grace (2010) proposed and tested a model of employee-based brand equity (EBBE) that is essentially a model of internal marketing. One difficulty of building a general model of internal marketing is that we can always incorporate more variables into such a general model. Another difficulty lies in the complexity of the causal relationships between variables. The causal relationships may exist between different dimensions of internal marketing, and between variables belonging to the same dimension. Because the possible relationships between and within dimensions of internal marketing are numerous, a complete and comprehensive illustration of them is not possible. This impossibility explains why there is here is no universally accepted and adopted internal marketing program (Papasolomou \& Vrontis, 2006). Therefore, instead of proposing such a general model, the author proposes a conceptual model based on the hierarchy of effects model (Lavidge, 1961). The 
hierarchy of effects model describes a process of purchasing that customers go through a series of steps that begins with awareness of product and results in buying behavior (Grover \& Vriens, 2006). Thus, it is used more as a principle than a general model and is flexible enough for marketing managers to develop their unique promotion strategy.

The conceptual model of the current study is based on the hierarchy of effects model that was originally applied to external marketing. To the best of the author's knowledge, this is the first time a conceptual model of internal marketing based on the hierarchy of effects model is presented. The conceptual model of the current study should be viewed as one possible example for crystallizing the hierarchy of effects model within the context of internal marketing. This approach is sufficiently flexible to allow firms and researchers to develop their own suitable internal marketing approaches or models by incorporating appropriate variables.

In the conceptual model based on the hierarchy of effects model, the current study expands internal marketing research by including several variables that have seldom been included in studies involving salespeople. These variables are leader-member exchange (LMX), ethical climate (EC), role clarity (RC), and organizational identification (OI). Several proposed relationships that have not been fully explored in previous studies are evaluated, including the relationship between EC and OI and that between RC and OI. On the one hand, the extent to which EC, LMX, and RC can be employed as business levers in internal marketing was evaluated following the hypotheses derived from the conceptual model. On the other hand, the empirical findings about the conceptual can be used to test the validity of applying the hierarchy of effects model to internal marketing.

The empirical findings of the current study confirm the the validity of applying the hierarchy of effects model to internal marketing. Thus, the roles played by EC, LMX, RC, and OI within the context of internal marketing can be illustrated in our conceptual model. From these findings some practical suggestions can be derived for life insurance industry.

\section{Conceptual Model Based on the Hierarchy of Effects Model}

The conceptual model is based on the hierarchy of effects model (Lavidge, 1961), which was originally applied to external marketing. Following this approach, disinterested consumers to do not instantaneously become convinced customers of a given firm. Potential customers progress through a series of steps in which they learn about a product through marketing, subsequently forming feelings regarding the product in question and finally making their purchase decision. This process is assumed to comprise three stages: the cognitive dimension, affective dimension, and conative dimension (Pérez \& del Bosque, 2014). Marketing managers use a set of managerial activities to convey their messages to target audiences in order to create a positive influence on customer thoughts and beliefs, invoke customer interest and desire, and elicit the targeted customer behavior (Clow \& Baack, 2007).

Generally, internal marketing refers to a set of managerial activities that begin with creating a positive influence on employee thoughts and beliefs by applying marketing strategies to employees, resulting in positive effects on employee behavior and positive organizational outcomes such as high service quality (Lings \& Greenley, 2005). The process of internal marketing is similar to that of external marketing. Therefore, we apply the hierarchy of effects model to internal marketing in this study.

The conceptual model of the current study consists of the relationships among LMX, EC, RC, job satisfaction (JS), OI, and organizational commitment (OC) regarding life insurance salespeople (Figure 1). EC, LMX, and RC act as cognitive variables directly resulting from managerial activities. EC dictates a firm's ethical values and the behaviors that are expected, supported, and rewarded, referring to how the organization shapes the routine behaviors of its members (Schwepker, 2001). In other words, EC can influence the thoughts, beliefs, behavioral intentions, and behaviors of individuals in an organization. Incorporating EC into internal marketing provides managers with an additional means of improving internal marketing outcomes and forms the basis of other internal marketing levers. Therefore, we assume that EC is more fundamental than other cognitive variables, as shown in Figure 1.

The relationships between cognitive variables and the expected behavioral intention or actions of employees have not consistently been significantly supported by the empirical findings of previous studies, even if these relationships have been theoretically well founded. Therefore, between the cognitive and conative variables, we introduce the affective variables as mediators. The affective variables refer to the affective responses of employees to the internal marketing activities of managers, acting as the antecedents of the conative variables. JS is likely the most frequently investigated affective variable in the domain of internal marketing (Ahmed \& Rqfig, 2003; King \& Grace, 2010). OI and OC are viewed as conative variables. The effects of EC on them are more likely to be mediated by other variables. LMX and $\mathrm{RC}$ act as independent internal marketing practices that are positively related to JS, which in turn positively influences employee OC and OI. JS mediates the effects of EC, LMX, and RC on OI and OC. 


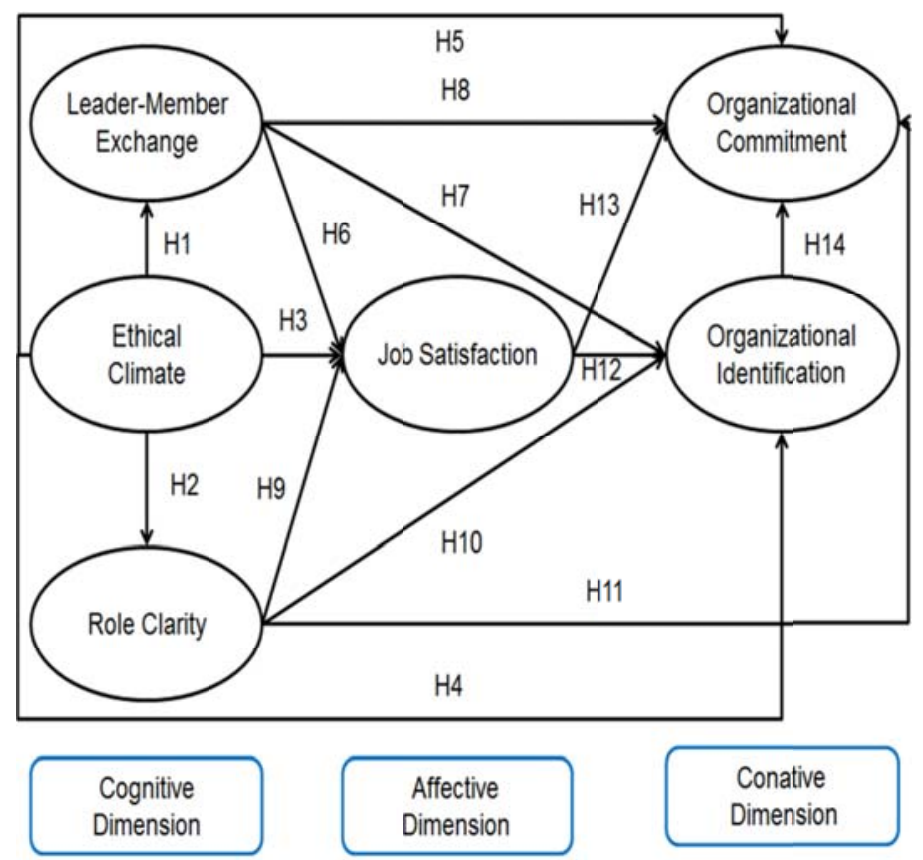

Figure 1. Conceptual model

\section{Hypotheses Development}

\section{$3.1 E C$}

To test the unique role of EC, five hypotheses regarding its effects on other variables are proposed. EC embodies the norms and patterns of typical interaction and determines stakeholder trust in the "rules of the game" maintained in an organization (Ahmed \& Rqfig, 2003; Fein et al., 2013; Stachowicz-Stanusch \& Simha 2013). EC may be viewed as the interpersonal atmosphere that can enable feelings of trust among members of an organization (Fein et al., 2013). These feelings of trust are crucial constituents of LMX. Effective LMX relationships are characterized by high levels of mutual trust and respect that exceed formal employment expectations (Bauer \& Green, 1996). Therefore, we propose the following hypothesis:

H1: EC is positively associated with LMX.

$\mathrm{RC}$ is defined as "an individual's understanding of job expectations, the process of fulfilling these expectations, and the consequences of one's role performance" (Hartenian \& Hadaway, 1994). EC relates to employee perceptions of an organization's norms, whereby ethical content provides cues regarding expected, supported, and rewarded behaviors (Jaramillo et al., 2006). These norms can aid employees in understanding the expectations that the organization has for them, and reduce role ambiguity (Jaramillo et al., 2006). Therefore, we propose the following hypothesis:

H2: EC is positively associated with RC.

The positive association of EC with JS is supported by empirical evidence. Vitell \& Davis (1990) showed that the JS of employees is higher when top management emphasizes ethical behavior, as well as and when they are optimistic about the relationship between ethics and success within their firms. Mulki et al. (2006) found that EC is a significant predictor of JS. We thus propose the following hypothesis:

H3: EC is positively associated with JS.

In the process of classifying themselves and other individuals into social groups, people adopt unique group norms that guide their behavior (Ellemers et al., 2004); they behave similarly to other group members. These norms concretize the EC. The EC thus enhances the similarities between group members on which OI is built. In addition, members who positively perceive the EC created by an organization identify strongly with the organization (DeConinck, 2011a). Thus, we propose the following hypothesis:

H4: EC is positively associated with OI.

$\mathrm{OC}$ is viewed as the reciprocal exchange relationships within an organization. It is based on trust in the "rules of the game" maintained in the organization (Ahmed \& Rafig, 2003). To some degree, these relationships can be enhanced by an EC that ensures high functioning of these rules (Mulki et al., 2006). Therefore, we propose the following hypothesis:

H5: EC is positively associated with OC. 


\section{$3.2 L M X$}

To specify the extent to which LMX can be employed as an internal marketing practice, three hypotheses regarding its effects on other variables are proposed. LMX evolved from social exchange theory (Blau, 1964) and the norm of reciprocity (Homans, 1958). Social exchanges occur only when two parties must each give and receive something (DeConinck, 2011b). Over time, norms of reciprocity develop, governing the exchanges between the parties (Blau 1964; Homans, 1958). In high-quality LMX, the leader provides substantial support and resources to the subordinate. The subordinate is thus obligated to reciprocate affectively, intentionally, or behaviorally.

High-quality LMX also endows employees with positive social-emotional experiences, which are positively associated with JS (Volmer et al., 2011). In the process of social exchange, the perception of oneness with or belongingness in an organization (i.e., OI) (Loi et al., 2014) and the psychological bond of the employee with the organization (i.e., OC) (Joo 2010; Porter et al., 1974) are enhanced. Therefore, we propose the following hypotheses:

H6: The quality of LMX is positively associated with JS.

H7: The quality of LMX is positively associated with OI.

H8: The quality of LMX is positively associated with OC.

$3.3 R C$

For specifying the extent to which RC can be employed as an internal marketing practice, three hypotheses regarding its effects on other variables are proposed. Empirical findings on the relationship between RC and JS have been mixed (Van Sell et al., 1981). To our knowledge, no study has examined the relationship between RC and OI. Furthermore, prior studies have supported the contention that decreased RC results in lower OC (Dubinsky \& Hartley, 1986).

Employees experience RC when they are sure of what is expected from them in certain employment situations. In the absence of RC, employees experience role stress. Studies have generally indicated that the influence of role stress on job outcomes is negative (Boshoff \& Mels, 1995). Therefore, we can infer that the influence of RC on most job outcomes is positive. Positive effects of RC on JS, OI, and OC are assumed for this reason.

H9: RC positively affects JS.

H10: RC positively affects OI.

H11: RC positively affects OC.

3.4 JS

According our conceptual model, JS acts as an affective variable that has direct effects on conative variables and mediates the relationships between cognitive variables and conative variables. Here, JS is selected because it is likely the most frequently investigated precursor to positive employee behavioral intentions and subsequent behaviors (Van Dick et al., 2004). The direct effects of JS on conative variables are the necessary condition of its mediating effects. Therefore, only hypotheses regarding direct effects are presented herein.

JS is an antecedent of OI (De Moura et al., 2009). Furthermore, a positive association between JS and OC has been identified in previous studies (Johnston et al., 1990; Porter et al., 1974). Although the causal direction is ambiguous (Jernigan et al., 2002), there is strong evidence that OC is a consequence variable of JS, contrasting with the concept that JS is a consequence variable of OC (Schwepker, 2001). Therefore, two hypotheses regarding the effects of JS on conative variables are proposed as follows:

H12: JS positively affects OI.

H13: JS positively affects OC.

$3.5 \mathrm{OI}$

OC and OI are highly correlated but distinct variables (Riketta, 2005). Bedeian (2007) indicated that OI is an antecedent of OC. Meyer et al. (2006) further suggested that OC mediates the effects of OI on employee behavioral intention and outcome. Therefore, final hypothesis is proposed as follows:

H14: OI positively affects OC.

\section{Questionnaire Design and Data Collection}

A composite questionnaire composed of seven sections was created for the current study. In section 1, the seven-item scale developed by Scandura et al. (1986) was used to measure LMX. Items LMX2, LMX3, and LMX6 were excluded to improve model conformity because of high modification indices (M.I.) par change value. In section 2, EC was measured using Schwepker's (2001) seven-item scale, which has been widely applied in previous studies. Items EC1 
and EC7 were excluded because their standardized regression weights are lower than 0.5 (Fornell \& Larcker, 1981). In section 3, RC was measured using the six-item scale developed by Low et al. (2001). Items RC1, RC5, and RC6 were excluded because of high M.I. par change value. In section 4, we applied the five-item scale developed by King \& Grace (2010) to measure JS. Items JS4 and JS5 were excluded because of high M.I. par change value. In section 5, OC was measured using the scale developed by Allen \& Meyer (1990). Items OC4, OC5, OC6, OC7, and OC8 were excluded because of high M.I. par change value. In section 6, the six-item scale developed by Mael \& Ashforth (1992) was used to measure OI. Items OI4, OI5, and OI6 were excluded because of high M.I. par change value. Responses to items in the aforementioned six sections were measured on a 7-point Likert scale anchored at 1 (strongly disagree) and 7 (strongly agree). Demographic questions were included in section 7.

A considerable number of studies have suggested that common method variance influences measures applied in a given field and the relationships between these measures (Podsakoff et al., 2003). If the items are ambiguous, respondents may respond systematically by using their own heuristic or may respond randomly (Podsakoff et al., 2003). For reducing item ambiguity and controlling common method variance, every point on the response scale was labeled (Krosnick, 1991). In addition, we introduced a proximal separation between the measurements of predictor and criterion variables by randomly positioning measures of the same construct apart from each other (Weijters et al., 2009). This proximal separation could prevent the respondents from using their prior responses to answer subsequent questions, thereby reducing common method variance (Podsakoff et al., 2003).

To test the proposed model and related hypotheses, data were collected by surveying life insurance salespeople working for major life insurance companies in Taiwan. These salespeople were responsible for selling insurance policies through direct selling. We telephoned potential participating organizations to determine the managers' willingness to participate in this study. Sales managers, to whom questionnaires were sent, were asked to distribute copies of the survey to their sales teams. Respondents were asked to send completed surveys in a sealed envelope directly to the researcher to keep them anonymous. A total of 800 survey instruments were distributed and 653 were returned; nine were discarded because of missing data. Therefore, 644 life insurance salespeople from several major life insurance firms in Taiwan formed the basis of the empirical analysis in this study. The majority of respondents are female $(67.9 \%)$ and younger than 40 years old $(63 \%)$. More than half $(57.2 \%)$ of the respondents have sales experience of less than 6 years, while $30.6 \%$ of them have more than 9 years of experience.

\section{Data Analysis and Results}

Internal consistency, construct reliability, convergent validity, and discriminant validity were evaluated through confirmatory factor analysis of all data collected. As indicated in Table 1, all values of Cronbach's $\alpha$ were between 0.854 and 0.924 , exceeding the threshold of 0.7 , indicating adequate internal consistency. All values of composite reliability (CR) indices were between 0.855 and 0.926 , higher than the threshold of 0.6 , indicating a favorable level of construct reliability. All values of average variance extracted (AVE) were between 0.663 and 0.768 , higher than the threshold of 0.5 . All estimated regression weights of items for the latent variables were significant at the 0.001 level and over the threshold of 0.5 . Therefore, the measurement scales showed strong convergent validity.

Table 1. Construct measure reliability and validity

\begin{tabular}{|c|c|c|c|c|c|c|c|c|}
\hline Construct & Indicator & Standardized & $\begin{array}{l}\text { Regression } \\
\text { weight }\end{array}$ & SE & $\mathrm{P}$ & $\begin{array}{l}\text { Cronbach's } \\
\alpha\end{array}$ & CR & AVE \\
\hline \multirow[t]{4}{*}{ LMX } & LMX1 & 0.790 & 1.000 & & & 0.919 & 0.920 & 0.742 \\
\hline & LMX4 & 0.910 & 1.162 & 0.044 & $<0.001$ & & & \\
\hline & LMX5 & 0.910 & 1.144 & 0.043 & $<0.001$ & & & \\
\hline & LMX7 & 0.830 & 1.006 & 0.043 & $<0.001$ & & & \\
\hline \multirow[t]{4}{*}{$\mathrm{EC}$} & EC2 & 0.889 & 1.000 & & & 0.924 & 0.926 & 0.759 \\
\hline & EC3 & 0.916 & 0.969 & 0.028 & $<0.001$ & & & \\
\hline & EC4 & 0.924 & 1.040 & 0.029 & $<0.001$ & & & \\
\hline & EC6 & 0.743 & 0.766 & 0.033 & $<0.001$ & & & \\
\hline \multirow[t]{3}{*}{$\mathrm{RC}$} & $\mathrm{RC} 2$ & 0.838 & 1.000 & & & 0.892 & 0.894 & 0.737 \\
\hline & $\mathrm{RC} 3$ & 0.901 & 1.021 & 0.039 & $<0.001$ & & & \\
\hline & $\mathrm{RC} 4$ & 0.835 & 1.016 & 0.041 & $<0.001$ & & & \\
\hline \multirow[t]{3}{*}{ JS } & JS1 & 0.813 & 1.000 & & & 0.907 & 0.908 & 0.768 \\
\hline & JS 2 & 0.916 & 1.106 & 0.041 & $<0.001$ & & & \\
\hline & JS 3 & 0.896 & 1.103 & 0.041 & $<0.001$ & & & \\
\hline \multirow[t]{3}{*}{ OI } & OI1 & 0.845 & 1.000 & & & 0.854 & 0.855 & 0.663 \\
\hline & OI2 & 0.829 & 0.923 & 0.044 & $<0.001$ & & & \\
\hline & OI3 & 0.767 & 0.819 & 0.041 & $<0.001$ & & & \\
\hline \multirow[t]{3}{*}{$\mathrm{OC}$} & $\mathrm{OC} 1$ & 0.878 & 1.000 & & & 0.895 & 0.897 & 0.744 \\
\hline & $\mathrm{OC} 2$ & 0.870 & 0.952 & 0.035 & $<0.001$ & & & \\
\hline & OC3 & 0.839 & 1.057 & 0.041 & $<0.001$ & & & \\
\hline
\end{tabular}

Note: $\mathrm{SE}=$ standard error; $\mathrm{CR}=$ composite reliability; $\mathrm{AVE}=$ average variance extracted. 
The procedure proposed by Torkzadeh et al. (2003) and Fornell \& Larcker (1981) was employed to determine discriminant validity. Discriminant validity is achieved when the value of 1 is not included in the confidence interval (Bagozzi \& Phillips, 1982). The results of Table 2 showed that the value of 1 was clearly not included in any computed confidence interval, supporting the discriminate validity of all constructs.

For detecting common method variance, the unmeasured latent method construct (ULMC) technique was applied. The congeneric model, which has a better model fit than that of the noncongeneric model, was compared with the constrained model. If the congeneric model was nonsignificantly different from the constrained model $\left(\Delta X^{2}=20.363\right.$, $\Delta \mathrm{DF}=15, \mathrm{P}=0.158$ ), this indicated that there was no evidence of common method variance (Podsakoff et al., 2012).

Table 2. Correlation coefficients and their confidence intervals

\begin{tabular}{|c|c|c|c|c|c|c|}
\hline & LMX & $\mathrm{EC}$ & $\mathrm{RC}$ & JS & $\mathrm{OI}$ & $\mathrm{OC}$ \\
\hline LMX & 1 & 0.001 & 0.003 & 0.003 & 0.002 & 0.002 \\
\hline EC & $\begin{array}{l}0.537 \\
(0.459 \sim 0.619)\end{array}$ & 1 & 0.002 & 0.002 & 0.002 & 0.002 \\
\hline $\mathrm{RC}$ & $\begin{array}{l}0.290 \\
(0.193 \sim 0.376)\end{array}$ & $\begin{array}{l}0.313 \\
(0.224 \sim 0.406)\end{array}$ & 1 & 0.003 & 0.003 & 0.002 \\
\hline JS & $\begin{array}{l}0.562 \\
(0.471 \sim 0.633)\end{array}$ & $\begin{array}{l}0.386 \\
(0.284 \sim 0.474)\end{array}$ & $\begin{array}{l}0.345 \\
(0.240 \sim 0.432)\end{array}$ & 1 & 0.001 & 0.002 \\
\hline OI & $\begin{array}{l}0.644 \\
(0.566 \sim 0.716)\end{array}$ & $\begin{array}{l}0.744 \\
(0.671 \sim 0.807)\end{array}$ & $\begin{array}{l}0.327 \\
(0.227 \sim 0.415)\end{array}$ & $\begin{array}{l}0.486 \\
(0.395 \sim 0.576)\end{array}$ & 1 & 0.002 \\
\hline $\mathrm{OC}$ & $\begin{array}{l}0.787 \\
(0.703 \sim 0.849)\end{array}$ & $\begin{array}{l}0.610 \\
(0.517 \sim 0.964)\end{array}$ & $\begin{array}{l}0.301 \\
(0.193 \sim 0.391)\end{array}$ & $\begin{array}{l}0.564 \\
(0.468 \sim 0.644)\end{array}$ & $\begin{array}{l}0.743 \\
(0.659 \sim 0.809)\end{array}$ & 1 \\
\hline
\end{tabular}

Note: The $\mathrm{p}$ values are shown above the diagonal. The coefficient coefficients and their respective $95 \%$ confidence intervals are illustrated beneath the diagonal.

To access the overall model conformity, a set of fit indices were applied, as reported in Table 3. The model chi square $\left(\mathrm{X}^{2}\right)$ reached a statistically significant level. This may have been because of the sample size (Jöreskog \& Sörbom, 1993). Carmines \& McIver (1981) suggested using the normed chi square (X2/DF) to address the sensitivity of the $\mathrm{X}^{2}$ statistic. The value of X2/DF was 3.672, under the recommended tolerance threshold of 5 (Bollen, 1989). CFI $=0.959$, SRMR $=$ 0.045 , and RMSEA $=0.065$, indicating reasonable model fit.

Table 3. Effect decomposition

\begin{tabular}{|c|c|c|c|c|c|c|}
\hline & $\begin{array}{l}\text { Unstandardized } \\
\text { Direct effects }\end{array}$ & Standardized & $\begin{array}{l}\text { Unstandardized } \\
\text { Indirect effects }\end{array}$ & Standardized & $\begin{array}{l}\text { Unstandardized } \\
\text { Total effects }\end{array}$ & Standardized \\
\hline H1:EC->LMX & $\begin{array}{l}0.515 \\
(0.001)\end{array}$ & $\begin{array}{l}0.540 \\
(0.001)\end{array}$ & 0 & 0 & $\begin{array}{l}0.515 \\
(0.001)\end{array}$ & $\begin{array}{l}0.540 \\
(0.001)\end{array}$ \\
\hline $\mathrm{H} 2: \mathrm{EC}->\mathrm{RC}$ & $\begin{array}{l}0.292 \\
(0.002)\end{array}$ & $\begin{array}{l}0.318 \\
(0.002)\end{array}$ & 0 & 0 & $\begin{array}{l}0.292 \\
(0.002)\end{array}$ & $\begin{array}{l}0.318 \\
(0.002)\end{array}$ \\
\hline H3:EC -> JS & $\begin{array}{l}0.071 \\
(0.112)\end{array}$ & $\begin{array}{l}0.075 \\
(0.121)\end{array}$ & $\begin{array}{l}0.300 \\
(0.001)\end{array}$ & $\begin{array}{l}0.316 \\
(0.002)\end{array}$ & $\begin{array}{l}0.371 \\
(0.001)\end{array}$ & $\begin{array}{l}0.391 \\
(0.002)\end{array}$ \\
\hline $\mathrm{H} 4: \mathrm{EC}->\mathrm{OI}$ & $\begin{array}{l}0.492 \\
(0.001)\end{array}$ & $\begin{array}{l}0.540 \\
(0.001)\end{array}$ & $\begin{array}{l}0.188 \\
(0.002)\end{array}$ & $\begin{array}{l}0.206 \\
(0.002)\end{array}$ & $\begin{array}{l}0.680 \\
(0.01)\end{array}$ & $\begin{array}{l}0.747 \\
(0.002)\end{array}$ \\
\hline $\mathrm{H} 5: \mathrm{EC}->\mathrm{OC}$ & $\begin{array}{l}0.062 \\
(0.394)\end{array}$ & $\begin{array}{l}0.059 \\
(0.400)\end{array}$ & $\begin{array}{l}0.586 \\
(0.001)\end{array}$ & $\begin{array}{l}0.554 \\
(0.001)\end{array}$ & $\begin{array}{l}0.648 \\
(0.001)\end{array}$ & $\begin{array}{l}0.613 \\
(0.001)\end{array}$ \\
\hline H6:LMX->JS & $\begin{array}{l}0.469 \\
(0.002)\end{array}$ & $\begin{array}{l}0.473 \\
(0.002)\end{array}$ & 0 & 0 & $\begin{array}{l}0.469 \\
(0.002)\end{array}$ & $\begin{array}{l}0.473 \\
(0.002)\end{array}$ \\
\hline H7:LMX->OI & $\begin{array}{l}0.270 \\
(0.004)\end{array}$ & $\begin{array}{l}0.283 \\
(0.003)\end{array}$ & $\begin{array}{l}0.047 \\
(0.020)\end{array}$ & $\begin{array}{l}0.049 \\
(0.020)\end{array}$ & $\begin{array}{l}0.317 \\
(0.003)\end{array}$ & $\begin{array}{l}0.332 \\
(0.002)\end{array}$ \\
\hline H8:LMX->OC & $\begin{array}{l}0.525 \\
(0.003)\end{array}$ & $\begin{array}{l}0.474 \\
(0.002)\end{array}$ & $\begin{array}{l}0.183 \\
(0.001)\end{array}$ & $\begin{array}{l}0.165 \\
(0.001)\end{array}$ & $\begin{array}{l}0.708 \\
(0.002)\end{array}$ & $\begin{array}{l}0.639 \\
(0.002)\end{array}$ \\
\hline H9:RC->JS & $\begin{array}{l}0.199 \\
(0.002)\end{array}$ & $\begin{array}{l}0.193 \\
(0.002)\end{array}$ & 0 & 0 & $\begin{array}{l}0.199 \\
(0.002)\end{array}$ & $\begin{array}{l}0.193 \\
(0.002)\end{array}$ \\
\hline $\mathrm{H} 10: \mathrm{RC}->\mathrm{OI}$ & $\begin{array}{l}0.041 \\
(0.309)\end{array}$ & $\begin{array}{l}0.041 \\
(0.306)\end{array}$ & $\begin{array}{l}0.020 \\
(0.016)\end{array}$ & $\begin{array}{l}0.020 \\
(0.015)\end{array}$ & $\begin{array}{l}0.061 \\
(0.016)\end{array}$ & $\begin{array}{l}0.061 \\
(0.015)\end{array}$ \\
\hline $\mathrm{H} 11: \mathrm{RC}->\mathrm{OC}$ & $\begin{array}{l}0.001 \\
(0.944)\end{array}$ & $\begin{array}{l}0.001 \\
(0.945)\end{array}$ & $\begin{array}{l}0.048 \\
(0.005)\end{array}$ & $\begin{array}{l}0.042 \\
(0.005)\end{array}$ & $\begin{array}{l}0.050 \\
(0.005)\end{array}$ & $\begin{array}{l}0.043 \\
(0.005)\end{array}$ \\
\hline H12:JS ->OI & $\begin{array}{l}0.100 \\
(0.022)\end{array}$ & $\begin{array}{l}0.105 \\
(0.020)\end{array}$ & 0 & 0 & $\begin{array}{l}0.100 \\
(0.022)\end{array}$ & $\begin{array}{l}0.105 \\
(0.020)\end{array}$ \\
\hline H13:JS ->OC & $\begin{array}{l}0.122 \\
(0.006)\end{array}$ & $\begin{array}{l}0.110 \\
(0.007)\end{array}$ & $\begin{array}{l}0.040 \\
(0.021)\end{array}$ & $\begin{array}{l}0.036 \\
(0.018)\end{array}$ & $\begin{array}{l}0.162 \\
(0.001)\end{array}$ & $\begin{array}{l}0.146 \\
(0.001)\end{array}$ \\
\hline H14:OI->OC & $\begin{array}{l}0.397 \\
(0.001)\end{array}$ & $\begin{array}{l}0.342 \\
(0.001)\end{array}$ & & & $\begin{array}{l}0.397 \\
(0.001)\end{array}$ & $\begin{array}{l}0.342 \\
(0.001)\end{array}$ \\
\hline
\end{tabular}

Note: $\mathrm{X}^{2}(156)^{=} 580.952(0.000), \mathrm{X}^{2} / \mathrm{DF}=3.724, \mathrm{CFI}=0.959, \mathrm{SRMR}=0.045$, and RMSEA $=0.065$, at the $90 \%$ confidence interval 0.059 0.071. $\mathrm{P}$ values are in parentheses. 
The construct relationships and significances hypothesized in the conceptual model were examined using structural equation modeling. The effect decomposition is presented in Table 3 and Figure 2. We used these results to test the proposed hypotheses. To clearly illustrate the mediating effects, the sequence of presentation for the hypothesis findings does not follow their ordinal numbers.

First, the paths JS- $>$ OI, JS- $>$ OC, and OI- $>$ OC are significant at the 0.05 level, supporting H12-14.

Second, the paths LMX->JS, LMX->OI and LMX->OC were all significant at the 0.01 level, supporting H6-8. The regression weights of LMX on OI and OC were decomposed into direct effects and indirect effects; these two relationships are implicitly assumed to be mediated by JS. The method of bootstrapping was used to estimate the two-tailed significance for the total effects, total indirect effects, and direct effects (Bollen \& Stine, 1990). The number of bootstrap samples was set at 1000. The findings of the bias-corrected percentile method are presented in Table 2. As shown in Table 2, the direct and indirect effects of LMX on OI and OC were all positive and significant. These findings imply that the effect of LMX on OI and OC is partially mediated by JS (Andrews et al., 2004).
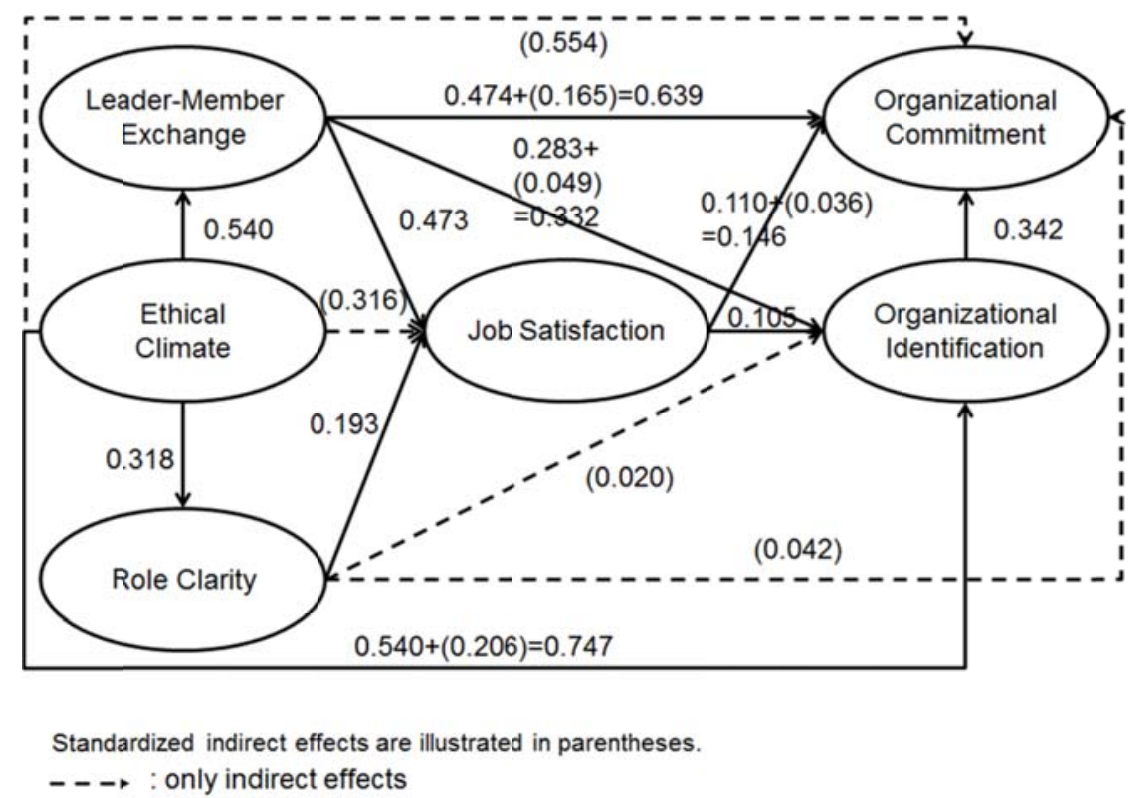

Figure2. Standardized total effects of the structural model

Third, the paths RC- $>$ JS, RC- $>$ OI, and RC- $>$ OC were all significant at the 0.05 level, supporting H9-11. For the paths $\mathrm{RC}->\mathrm{OI}$ and $\mathrm{RC}->\mathrm{OC}$, neither of the standardized estimates of the two direct effects was significant, whereas the standardized estimates of the two indirect effects were all significant at the 0.05 level. In addition, the direct effects of RC- $>$ JS, JS- $>$ OI and JS- $>$ OC were significant. These findings imply that the effects of RC on OI and OC are all fully mediated by JS (Andrews et al., 2004).

Fourth, the paths EC->LMX, EC->RC, EC->JS, EC->OI, and EC->OC were all significant at the 0.05 level, supporting H1-5.

The direct effect of EC->JS was nonsignificant, whereas the indirect effect was statistically significant at the 0.01 level. The direct effects of EC->LMX, LMX->JS, EC->RC, and RC->JS were all statistically significant. Therefore, the path EC->JS is fully mediated by LMX and RC (Andrews et al., 2004).

The path EC->OI is partially medicated by RC and JS; the direct effect and indirect effects of EC->OI and the direct effects of EC->RC, RC->JS, and JS->OI were all statistically significant at the 0.05 level.

The path EC->OC is fully mediated by LMX, JS, and OI; its direct effect was not significant, whereas its indirect effects and the direct effects of EC->LMX, LMX->OC, LMX->OI, LMX->JS, JS->OI, and OI->OC were all statistically significant at the 0.05 level.

\section{Discussion and Conclusion}

This study expands the literature of internal marketing by applying the principles of the hierarchy of effects model to internal marketing and by examining the effects of EC, LMX, and RC on job outcomes in the context of internal marketing.

Several findings in this study indicate the fundamental role of EC as a cognitive variable in our conceptual model; EC 
has strong direct effect on LMX and RC, which are assumed to be lower-ranking cognitive variables that are directly associated with internal marketing consequences. Although EC has no significant direct effect on JS, its total effect is greater than that of RC, which significantly affects JS. EC has a stronger influence on OI compared with other antecedents. In addition, the direct effect of EC on OI is stronger than the sum of the indirect effects of EC on OI. These findings imply that OI of life insurance salespeople is primarily influenced by EC. Among the five antecedents of OC, the total effect of EC is lower than that of LMX only, although EC has no significant direct effect on OC. These findings confirm that $\mathrm{EC}$ is a basis for managerial activities concerning internal marketing. Based on these findings, this study evidences a crucial link between EC and internal marketing.

It is also critical that the empirical findings of this study support the validity of applying the hierarchy of effects model to internal marketing. All hypothesized total effects (i.e., regression weights) in the conceptual model are significant at the 0.05 level. Furthermore, all mediating effects of JS on the paths LMX->OI, LMX->OC, RC->OI, RC- $>$ OC, EC- $>0$, and EC- $>\mathrm{OC}$ were confirmed in the empirical analysis. These findings are consistent with the theoretical implications based on the hierarchy of effects model, according to which the conative outcomes of internal marketing may not be directly influenced by cognitive variables. JS, which belongs to the affective dimension, appears to act as a mediator between the cognitive and conative variables.

The findings of this study may provide useful suggestions for financial service industries and life insurance companies. The present study indicates that the life insurance industry, and possibly the financial service industry, should focus on the influence of managerial activities on salespeople's affective responses such as JS. JS represents a crucial link between salespeople's perceptions of managerial activities and their behavioral intentions and actions. For life insurance companies, which operate in a fiercely competitive service-intensive industry, a critical competitive advantage is gained by retaining satisfied salespeople who will deliver high-quality service.

Financial products are intangibles. Among them, life insurance policies are relatively complicated, and it is often difficult for prospective clients to understand the content of life insurance policies. Compared with average policyholders, life insurance salespeople have abundant expertise regarding their products. The existence of a steep asymmetry leads to policyholders' heavy reliance on salespeople. The life insurance salespeople are in an advantageous position relative to their policyholders; this advantageous position may be exploited either by companies or individual salespeople. Similar situations are frequently found in other financial service industries (Taek Yi et al., 2012). Moreover, salespeople' jobs are highly demanding because of their intensive interactions with policyholders. With pressure to missell products to customers, owing to firm requirements, salespeople may have less JS because of job stress.

Our findings indicate that EC may play a fundamental role in the internal marketing process. Emphasizing EC in internal marketing could improve ethical values in the life insurance industry and enhance life insurance salespeople' OI and OC; LMX and RC could play a complementary role in this regard. Managerial activities leading to EC, RC, and LMX, which may reduce the pressure of misselling and job stress, appear to be practical approaches for increasing salespeople's JS.

Such a process is effective according to the conceptual model proposed in the present study, which is sufficiently flexible for life insurance companies, or companies in general, to incorporate other managerial activities and develop their own internal marketing approach. Therefore, a customized approach toward internal marketing could be developed for individual companies and industries by incorporating different managerial activities. Furthermore, future research could explore other conative outcomes such as organizational citizenship behaviors (King, \& Grace, 2010) and their relationships with cognitive and affective variables. Finally, we recommended applying the samples from firms in other industries to examine the stability of the findings.

\section{References}

Ahmed, P. K., \& Rafig, M. (2003). Internal marketing issues and challenges. European Journal of Marketing, 37(9), 1177-1186. http://dx.doi.org/10.1108/03090560310498813

Allen, N. J., \& Meyer, J. P. (1990). The measurement and antecedents of affective, continuance and normative commitment to the organization. Journal of Occupational Psychology, 63, 1-18. http://dx.doi.org/10.1111/j.2044-8325.1990.tb00506.x

Andrews, J. C., Netemeyer, R., Burton, S., Moberg, P., \& Christainsen, A. (2004). Understanding adolescent intentions to smoke: an examination of relationships among social influences, prior trial behaviors, and antitobacco campaign advertising. Journal of Marketing, 68(4), 110-123. http://dx.doi.org/10.1509/jmkg.68.3.110.34767

Bagozzi, R. P., \& Phillips, L. W. (1982). Representing and testing organizational theories: a holistic construal. Administrative Science Quarterly, 27(3), 459-489. http://dx.doi.org/10.2307/2392322

Bauer, T. N., \& Green, S. G. (1996). Development of leader-member exchange: a longitudinal test. Academy of 
Management Journal, 39(6), 1538-1567. http://dx.doi.org/10.2307/257068

Bedeian, A. G. (2007). Even if the tower is 'ivory', it isn't 'white:' understanding the consequences of faculty cynicism. Academy of Management Learning \& Education, 6(1), 9-32. http://dx.doi.org/10.5465/AMLE.2007.24401700

Blau, P. M. (1964). Exchange and power in social life. New York, NY: Wiley.

Bollen, K. A. (1989). Structural Equations with Latent Variables. New York, NY: Wiley.

Bollen, K. A., \& Stine, R. (1990). Direct and indirect effects: classical and bootstrap estimates of variability. Sociology Methodology, 20, 115-140. http://dx.doi.org/10.2307/271084

Boshoff, C., \& Mels, G. (1995). A causal model to evaluate the relationships among supervision, role stress, organizational commitment and internal service quality. European Journal of Marketing, 29(2), 23-42. http://dx.doi.org/10.1108/03090569510080932

Carmines, E., \& McIver, J. (1981). Analyzing models with unobserved variables: analysis of covariance structures. In G. Bohrnstedt, \& E. Borgatta (Eds.) Social measurement: current issues, 65-115. Beverly Hills, CA: Sage Publications.

Clow, K. E., \& Baack, D. (2007). Advertising design: message strategies and executional framework (3rd ed.). New York, NY: Pearson Education.

Cooper, J., \& Cronin, J. J. (2000). Internal marketing: a competitive strategy for the long-term care industry. Journal of Business Research, 48(3), 177-181. http://dx.doi.org/10.1016/S0148-2963(98)00084-8

De Moura, G. R., Abrams, D., Retter, C., Gunnarsdottir, S., \& Ando, A. (2009). Identification as an organizational anchor: how identification and job satisfaction combine to predict turnover intention. European Journal of Social Psychology, 39(4), 540-557. http://dx.doi.org/10.1002/ejsp.553

DeConinck, J. B. (2011a). The effects of ethical climate on organizational identification, supervisory trust, and turnover among salespeople. Journal of Business Research, 64(6), 617-624. http://dx.doi.org/10.1016/j.jbusres.2010.06.014

DeConinck, J. B. (2011b). The effects of leader-member exchange and organizational identification on performance and turnover among salespeople. Journal of Personal Selling and Sales Management, 31(1), 21-34. http://dx.doi.org/10.2753/PSS0885-3134310102

Dubinsky, A. J., \& Hartley, S. W. (1986). A path-analytic study of a model of salesperson performance. Journal of the Academy of Marketing Science, 14(1), 36-46. http://dx.doi.org/10.1007/BF02722111

Ellemers, N., De Gilder, D., \& Haslam, S. A. (2004). Motivating individuals and groups at work: a social identity perspective on leadership and group performance. Academy of Management Review, 29(3), 459-478. http://dx.doi.org/10.5465/AMR.2004.13670967

Fein, E. C., Tziner, A., Lusky, L., \& Palachy, O. (2013). Relationships between ethical climate, justice perceptions, and LMX. Leadership \& Organization Development Journal, 34(2), 147-163. http://dx.doi.org/10.1108/01437731311321913

Fornell, C., \& Larcker, D. F. (1981). Evaluating structural equation models with unobservable variables and measurement error. Journal of Marketing Research, 18(1), 39-50. http://dx.doi.org/10.2307/3151312

Hartenian, L. S., \& Hadaway, F. J. (1994). Antecedents and consequences of role perceptions: a path analytic approach. Journal of Applied Business Research, 10(2), 40-50. http://dx.doi.org/10.19030/jabr.v10i2.5937

Homans, G. C. (1958). Social behavior as exchange. American Journal of Sociology, 63(6), 597-606.

Jaramillo, F., Mulki, J. P., \& Solomon, P. (2006). The role of ethical climate on salesperson's role stress, job attitudes, turnover intention, and job performance. Journal of Personal Selling and Sales Management, 26(3), 271-282. http://dx.doi.org/10.2753/PSS0885-3134260302

Jernigan, I. E. III., Beggs, J. M., \& Kohut, G. F. (2002). Dimensions of work satisfaction as predictors of commitment type. Journal of Managerial Psychology, 17(7), 564-579. http://dx.doi.org/10.1108/02683940210444030

Johnston, M. W., Parasuraman, A., Futrell, C. M., \& Black, W. C. (1990). A longitudinal assessment of the impact of selected organizational influences on salespeople's organizational commitment during early employment. Journal of Marketing Research, 27(3), 333-344. http://dx.doi.org/10.2307/3172590

Joo, B. K. (2010). Organizational commitment for knowledge workers: the roles of perceived organizational learning culture, leader-member exchange quality, and turnover intention. Human Resource Development Quarterly, 21(1), 69-85. http://dx.doi.org/10.1002/hrdq.20031 
Jöreskog, K. G., \& Sörbom, D. (1993). LISREL 8: structural equation modeling with the SIMPLIS command language. Chicago, IL: Scientific Software International.

King, C., \& Grace, D. (2010). Building and measuring employee-based brand equity. European Journal of Marketing, 44(7/8), 937-971. http://dx.doi.org/10.1108/03090561011047472

Krosnick, J. A. (1991). Response strategies for coping with the cognitive demands of attitude measures in surveys. Applied Cognitive Psychology, 5(3), 213-236. http://dx.doi.org/10.1002/acp.2350050305

Lavidge, R. J. (1961). A model for predictive measurements of advertising effectiveness. Journal of Marketing, 25(6), 59-62. http://dx.doi.org/10.2307/1248516

Lings, I., \& Greenley, G. (2005). Measuring internal market orientation. Journal of Service Research, 7(3), 290-305. http://dx.doi.org/10.1016/S0148-2963(02)00274-6

Loi, R., Chan, K. W., \& Lam, L. W. (2014). Leader-member exchange, organizational identification, and job satisfaction: a social identity perspective. Journal of Occupational and Organizational Psychology, 87(1), 42-61. http://dx.doi.org/10.1111/joop.12028

Low, G. S., Gravens, D. W., Grant, K., \& Monrief, W. C. (2001). Antecedents and consequences of salesperson burnout. European Journal of Marketing, 35(5/6), 587-611. http://dx.doi.org/10.1108/03090560110388123

Mael, F. A., \& Ashforth, B. E. (1992). Alumni and their alma mater: a partial test of the refinement model of organizational identification. Journal of Organizational Behavior, 13(2), 103-123. http://dx.doi.org/10.1002/job.4030130202

Meyer, J. P., Becker, T. E., \& Van Dick, R. (2006). Social identities and commitments at work: toward an integrative model. Journal of Organizational Behavior, 27(5), 665-683. http://dx.doi.org/10.1002/job.383

Mulki, J. P., Jaramillo, F., \& Locander, W. (2006). Effects of ethical climate and supervisory trust on salespersons job attitudes and intentions to quit. Journal of Personal Selling and Sales Management, 26(1), 19-26. http://dx.doi.org/10.2753/PSS0885-3134260102

Papasolomou, I., \& Vrontis, D. (2006). Building corporate branding through internal marketing: the case of the UK retail bank industry. Journal of Product \& Brand Management, 15(1), 37-47. http://dx.doi.org/10.1108/10610420610650864

Pérez, A., \& Del Bosque, I. R. (2014). An integrative framework to understand how CSR affects customer loyalty through identification, emotions and satisfaction. Journal of Business Ethics, 129(3), 571-584. http://dx.doi.org/10.1007/s10551-014-2177-9

Podsakoff, P. M., MacKenzie, S. B., \& Podsakoff, N. P. (2012). Sources of method bias in social science research and recommendations on how to control it. Annual Review of Psychology, 63, 539-569. http://dx.doi.org/10.1146/annurev-psych-120710-100452

Podsakoff, P. M., MacKenzie, S. B., Lee, J. Y., \& Podsakoff, N. (2003). Common method biases in behavioral research: a critical review of the literature and recommended remedies. Journal of Applied Psychology, 88(5), 879-903. http://dx.doi.org/10.1037/0021-9010.88.5.879

Porter, L. W., Steers, R. M., Mowday, R. T., \& Boulian, T. V. (1974). Organizational commitment, job satisfaction and turnover: psychometric techniques. Journal of Applied Psychology, 59(5), 603-609. http://dx.doi.org/10.1037/h0037335

Riketta, M. (2005). Organizational identification: a meta-analysis. Journal of Vocational Behavior, 66(2), 358-384. http://dx.doi.org/10.1016/j.jvb.2004.05.005

Schlager, T., Bodderas, M., Maas, P., \& Cachelin, J. L. (2011). The influence of the employer brand on employee attitudes relevant for service branding: an empirical investigation. Journal of Services Marketing, 25(7), 497-508. http://dx.doi.org/10.1108/08876041111173624

Schwepker, C. H. J. (2001). Ethical climate's relationship to job satisfaction, organizational commitment and turnover in the sales force. Journal of Business Research, 54(1), 39-52. http://dx.doi.org/10.1016/S0148-2963(00)00125-9

Stachowicz, S. A., \& Simha, A. (2013). An empirical investigation of the effects of ethical climates on organizational corruption. Journal of Business Economics and Management, 14(sup1), 433-446. http://dx.doi.org/10.3846/16111699.2012.744345

Taek, Y. H., Dubinsky, A. J., \& Un Lim, C. (2012). Determinants of telemarketer misselling in life insurance services Journal of Services Marketing, 26(6), 403-418. http://dx.doi.org/10.1108/08876041211257891 
Torkzadeh, G., Koufteros, X., \& Pflughoeft, K. (2003). Confirmatory analysis of computer self-efficacy. Structural Equation Modeling, 10(2), 263-275. http://dx.doi.org/10.1207/S15328007SEM1002_6

Van Dick, R., Christ, O., Stellmacher, J., Wagner, U., Ahlswede, O., Grubba, C., ... Tissington, P. A. (2004). Should I stay or should I go? Explaining turnover intentions with organizational identification and job satisfaction. British Journal of Management, 15(4), 351-360. http://dx.doi.org/10.1111/j.1467-8551.2004.00424.x

Van Sell, M., Brief, A. P., \& Schuler, R. S. (1981). Role conflict and role ambiguity: integration of the literature and directions for future research. Human Relations, 34(1), 43-71. http://dx.doi.org/10.1177/001872678103400104

Vitell, S. J., \& Davis, D. L. (1990). The relationship between ethics and job satisfaction: an empirical investigation. Journal of Business Ethics, 9(6), 489-494. http://dx.doi.org/10.1007/BF00382842

Volmer, J., Niessen, C., Spurk, D., Linz, A., \& Abele, A. E. (2011). Reciprocal relationships between leader-member exchange (LMX) and job satisfaction: a cross-lagged analysis. Applied Psychology-an International Review, 60(4), 522-545. http://dx.doi.org/10.1111/j.1464-0597.2011.00446.x

Weijters, B., Geuens, M., \& Schillewaert, N. (2009). The proximity effect: the role of inter-item distance on reverse item bias. International Journal of Research in Marketing, 26(1), 2-12.

http://dx.doi.org/10.1016/j.jiresmar.2008.09.003 


\section{Appendix. All Constructs and Their Items}

Constructs and items

Leader-member relationship (LMX)

LMX1. My sales manager understands my problems and needs.

LMX 2. My sales manager recognizes my potential.

LMX 3. Regardless of how much formal authority my sales manager has built into his or her position, my sales manager would be personally inclined to use his or her power to help me solve problems in my work.

LMX 4. I can count on my sales manager to "bail me out" at his or her expense when I really need it.

LMX 5. My sales manager has enough confidence in me that he or she would defend and justify my decisions if I were not present to do so.

LMX 6. I usually know where I stand with my sales manager.

LMX 7. My working relationship with my sales manager is extremely effective.

Ethical climate (EC)

EC1. My company has a formal, written code of ethics.

EC 2. My company strictly enforces a code of ethics.

EC 3. My company has policies with regards to ethical behavior.

EC 4. My company strictly enforces policies regarding ethical behavior.

EC 5. Top management in my company has let it be known in no uncertain terms that unethical behaviors will not be tolerated.

EC 6. If a salesperson in my company is discovered to have engaged in unethical behavior that results primarily in personal gain (rather than corporate gain), she or he will be promptly reprimanded.

EC 7. If a salesperson in my company is discovered to have engaged in unethical behavior that results in primarily corporate gain (rather than personal gain), she or he will be promptly reprimanded.

Role clarity (RC)

$\mathrm{RC} 1$. My job has clear, planned goals and objectives.

RC 2 . I know that I have divided my time properly.

RC 3. I know what my responsibilities are.

RC 4. I know exactly what is expected of me.

RC 5. I feel certain about how much authority I have.

RC 6. My supervisor's explanation of what has to be done is clear.

Job satisfaction (JS)

JS1. I feel reasonably satisfied with my job.

JS 2. I feel a great sense of satisfaction from my job.

JS 3. I am satisfied with my overall job.

JS 4. I would not consider leaving my current job should another job opportunity be presented to me.

JS 5. I do not enjoy my job(R).

Organizational identification (OI)

OI 1. When somebody criticizes your company, it feels like a personal insult.

OI 2. I am very interested in what others think about my company.

OI 3. When I talk about this company, I usually say "we" rather than "they."

OI 4. This company's successes are my successes.

OI 5. When someone praises this company, it feels like a personal compliment.

OI 6. If a story in the media criticized this company, I would feel embarrassed.

Organizational commitment (OC)

OC1. I would be very happy to spend the rest of my career with this organization.

OC 2. I enjoy discussing my organization with people outside it.

OC 3. I really feel as if this organization's problems are my own.

OC 4. I think that I could easily become as attached to another organization as I am to this one (R).

OC 5. I do not feel like 'part of the family' at my organization (R).

OC 6. I do not feel 'emotionally attached' to this organization (R).

OC 7. This organization has a great deal of personal meaning for me.

OC 8 . I do not feel a strong sense of belonging to my organization (R).

\section{Copyrights}

Copyright for this article is retained by the author(s), with first publication rights granted to the journal.

This is an open-access article distributed under the terms and conditions of the Creative Commons Attribution license (http://creativecommons.org/licenses/by/4.0/). 